\title{
Analyzing the Futsal Strategic Plan in Sulaymaniyah Province and Providing Management Solutions
}

\author{
${ }^{1}$ Shamseddin Rezaei*, ${ }^{2}$ Heersh Khalid Ameen \\ ${ }^{1}$ Department of Sport Sciences, Faculty of Humanities, Ilam University, Ilam, Iran. ${ }^{2}$ Department of \\ Physical Education, Faculty of Basic Education, University of Garmian, Kalar, Iraq.
}

Submitted 17 June 2019; Accepted in final form 23 August 2019.

\begin{abstract}
Background. Futsal has attracted many enthusiasts these days due to its special attractiveness as well as the skillful performance of players. Objectives. This research was aimed at analyzing the futsal strategic plan in Sulaymaniyah province and providing management solutions. Methods. The present research is a descriptive-analytical and applied research. The statistical population consisted of professors, managers and experts of the Sulaymaniyah Football Association Board and Coaches and referees, total of 53 people. To determine the research sample, total population sampling was used and the whole society was selected as a sample $(\mathrm{N}=\mathrm{n})$. The research instrument was an interview and researcher-made questionnaire, based on exploratory study and rewrite of the basics and similar studies, whose content validity was confirmed by experts and with appropriate reliability $(\mathrm{Ra}=0.89)$. For the analysis of data, descriptive statistics, internal and external factors evaluation matrix, SWOT matrix, and TOWS matrix were used. Results. Holding scientific and academic courses for coaches and referees, lack of financial resources for spending on futsal sport, the existence of educational centers and universities in the province, and the lack of sponsors to invest and support futsal clubs were identified, respectively, as the most important strengths, weaknesses, Opportunities and threats. Also based on the internal and external factors matrix, the strategic situation of the futsal in Sulaimaniyah, Iraq, is located in the WO area. Conclusion. SWOT analysis finding shows that weaknesses and opportunities overcome strengths and threats, respectively, so conservative strategies (improving internal weaknesses by exploiting existing opportunities) should be used. Therefore, the strategies to increasing the number and variety of community events and sports festivals, maximum use of available sports space and facilities and organizing regular leagues and domestic and provincial matches have been identified and proposed to remove current condition of futsal in Sulaymaniyah province.
\end{abstract}

\section{KEYWORDS: Strategic Planning, Sulaimaniyah Futsal, Strategic Analysis, Internal and External Factors Matrix}

\section{INTRODUCTION}

In today's world, urbanization and significant technological advancement have created lowmobility jobs and reduced public mobility (1). This inactivity will increase diseases and, consequently, will increase the cost of treatment for both the government and the nation (2). Exercise as a strategic solution and as a cheap and enjoyable tool can solve this problem in a desirable way. The results of various studies show that should extend sport to their long-term plans; otherwise, one should expect the critical statistics of diseases, absence from work due to illness caused by inactivity, increased mortality and decrease the level of public health (3). Therefore, sport today is one of the most urgent needs and the most fundamental issues of human societies, so that few countries can be found

*. Corresponding Author:

Shamseddin Rezaei, Assistant Professor

E-mail: sh.rezaei@ilam.ac.ir 
without a sports organization. One of the most important goals of sport federations and organizations in any country is the development of sports and the increase of public participation in championship and recreation activities in favorite sport. Meanwhile, Futsal has attracted many enthusiasts these days due to its special attractiveness as well as the skillful performance of players. Futsal in addition to the heroic and honorable aspect in the national and international arena can have sweeping functions due to fun and low cost, such as other sports. including the joy and enjoyment, enrichment of leisure time, the acquisition of health and fitness, improving the working relationships, transplantation and social and lifestyle relationships, preventing and treating diseases, achieving the benefits and effects of exercise, happiness and safety, energy depletion and toxins disposal, weight management and weight loss and having fitness, Having social emotions, expanding interaction and social relationships (4). On the other hand, the issue of professionalization of the futsal has caused the popularity of it to be expanded at the level of the societies.

In recent years, organizations have to constantly monitor environmental factors due to high rates of change, turbulent and unpredictable environments, abundant competitive opportunities and threats, and by analyzing the perimeter environment, determine and control effective strategies, key and critical context and factors of success (5). Many management thinkers believe that one of the ways to internal and external linkages between programs and systems in today's turbulent environment is a comprehensive strategic management model. According to Rezaei and Nasir zadeh (2018), the strategic management is art and science of the planning, implementation, and control of multiple task decisions that enable the organization to achieve its long-term goals (6). Overall, planning, execution and control form the strategic management process, which interact with each other. Therefore, strategic planning is a part of the strategic management process in which the objectives and general lines of activities and missions of the organization or the headquarters of the events are determined in the long run (6). Many scholars have considered the importance of strategic planning in various aspects, and they all agree on the strategic alignment with the organization's desirable performance (7). Strategic planning will enable the organization to adapt its activities and services to meet the changing needs of the environment. This type of planning, if properly designed, leads to the selection of strategies and, if properly implemented, will lead to organizational excellence (8). Strategic planning enables the organization to adapt its activities and services to meet the changing needs of the environment. This planning not only provides a framework for program improvement, but also provides a framework for program restructuring, management and collaboration as well as for evaluating the organization's progress in these (9). Teixeira (2019) argues that strategic planning is a key element for organizational excellence and an essential tool for organizational effectiveness and sustainability (10). Therefore, all organizations have to pay special attention to strategic management and planning, obviously, sports organizations and institutions are no exception.

Currently, many sports organizations in the world, such as the National Olympic Committees, sports federations and ..., have developed strategic plans in the field of sports. As an example, the Football Association of England has published its Futsal Development Strategic Plan in the 20182024 perspective and the UK University Sports Association has also released its football and futsal strategy for the period 2015-2019.

A review of various studies suggests that in most studies, SWOT analysis has been used to formulate a strategic plan. This word is a shortened model of strengths (S), weaknesses (W), opportunities $(\mathrm{O})$ and threats $(\mathrm{T})$. This word is a shortened model of strengths, weaknesses, opportunities and threats. This technique is an important tool in decision making and generally used to systematic analysis of strategic conditions and identify internal and external factors in an organization's environment (6). Conservative strategies (WO), competitive strategies (ST) and defensive strategies (WT) to reach the point, where they can use aggressive strategies (SO) (11). The results of Kashef et al. (2018) showed that the Department of Sports and Youth of East Azerbaijan is located in the WD region and should use the strategy of increase and development about the championship sport (12). SWOT analysis in the research by Rezaei and Nasir Zadeh (2018) showed that the most important strengths, weaknesses, opportunities and threats, the development of the Iranian football industry, respectively, consisted of the presence of millions of fans and supporters in the country, deep financial debt and losing of clubs, Article 44 of 
constitution and the existence of cumbersome rules (Not necessarily in the form of a constitution or subject-matter) (6). McGillivary et al. (2018) believe that creating a "Live city" in today's living conditions is the most important strength of sport development (13). Hambrick et al. (2018) describes the lack of resources and affiliation of sports organizations with public funding as a major threat to sports organizations (14).

Iraq's Kurdish region, which has been through years of war and deprivation, can be fraught with psychological stress. Therefore, exercise can undoubtedly play a valuable role in reducing stress and enhancing the vitality and well-being of individuals and as a result the social and cultural development of that community. An overview of the structure, infrastructure, and human and inhuman resources of the Kurdistan, Iraq, shows that in the field of sport, there are many limitations and problems in comparison with advanced and developing societies. As in Sulaymaniyah, Iraq, with 15 cities, there are only 6 stadiums and one futsal team. Regarding the mentioned cases, the lack of a strategic plan and integrated approach Kurdistan, Iraq, in the field of futsal sport, this research seeks to answer the question of which strategies are desirable for the development of futsal sport in Iraq's Sulaimaniyah province.

\section{MATERIALS AND METHODS}

Methodology. This research is applied in terms of purpose, and descriptive-analytic in term of method of data collection that was conducted as a case study by examining the current situation and drawing a desirable situation in the area of designing a strategic plan for the development of futsal sport in Sulaimaniyah, Iraq.

Participants. The statistical population consisted of professors, managers and experts of the Sulaymaniyah Football Association Board and Coaches and referees, total of 53 people. To determine the research sample, total population sampling was used $(\mathrm{N}=\mathrm{n})$.

Tools. In this study, interviews, researchermade questionnaire and check documents were used to collect information. Validity of the questionnaire was determined using survey of specialists and its reliability by Cronbach's alpha coefficient (0.89).

Data Analysis. To analyze the data and the suitable strategies, Friedman test, weighting method, and external and internal factors evaluation matrix and internal and external matrix (IE) were utilized.

\section{RESULTS}

Descriptive findings showed that the mean and standard deviation of the age of respondents is $34.1 \pm 9.1$ years and the highest frequency is for those with baccalaureate education and the lowest frequency is for those with an associate degree.

In strategic studies, after examining the status quo, formulate a vision statement, mission statement, core values, and long-term goals. These items were compiled by the Football Federation and Football and Futsal Association Boards of Kurdistan region and are contained in the official documents of the federations and the committees; therefore, the vision statement, mission statement, core values, and long-term goals were approved after the Strategic Council review and were used as a basis for the formulation of the strategies. Reported as follows:

Vision Statement. "Developing an active lifestyle through outstanding futsal sports programs"

Mission Statement. "Providing recreational and competitive programs that promote sustainable opportunities in futsal by creating convenient and equal opportunities for players and workforce, and provide the background for transforming of Sulaymaniyah's Futsal Board into a leading and prominent one, in Kurdistan region and Iraq, by creating a skilled generation of futsal players".

Core Values: According to the working group of the development of a Futsal Sports Development Strategy Program in Sulaimaniyah, Iraq, the values most commonly agreed upon include:

1. Fairness and equality: In a way that there is equal access to sports opportunities, spaces and equipment to all stakeholders.

2. Respect for ethics and fair play: Priority should be given to ethics, fraternity and bravery in all sports environment, competitions and festivals.

3. Science-based sport: Observe the scientific principles of sport in all futsal activities.

Key Areas of Futsal Sport Development Performance in Sulaimaniyah Province. According to the Strategic Plan Development Committee, the key areas of futsal performance development in Sulaimaniyah Iraq include players, coaches, referees, hardware infrastructures and Software infrastructure (processes, activities and competitions). 
Meta goals of Futsal Sports Development in Sulaimaniyah Province. Meta goals of Futsal Sports Development in Sulaimaniyah Province include: Increasing the number of active players (both men and women), increasing human resources specialized in managing, coaching and judging futsal, developing hardware infrastructures and enhancing productive capacity utilization of sports complexes, scientific and practical developing and enhancing of activities, processes, competitions and events related to futsal sport and achieving national and international rankings.

The Strengths, Weaknesses, Opportunities and Threats of Futsal Development in Sulaimaniyah Province, Iraq. The formation of the working groups for the formulate the futsal sport development program in Sulaimaniyah province led to the identification of 8 strengths, 13 weaknesses, 8 opportunity and 5 threat point for the development of futsal sport in Sulaimaniyah. Prioritizing strengths based on the Friedman test showed that the most important strengths of Sulaymaniyah Football Association Board for the development of futsal include holding scientific and academic training courses for coaches and referees, having nationally acclaimed coaches and players and have an executive program for the Futsal in Sulaimaniyah, respectively. Prioritizing the weaknesses based on Friedman's test shows that the most important weaknesses of the Sulaymaniyah Football Association Board for futsal development include lack of funds for spending on futsal, Lack of proper sports facilities for futsal, and the lack of rules and regulations for private sector investment in futsal. Prioritizing opportunities based on Friedman's test shows that the most important opportunities for Sulaymaniyah Football Association Board for futsal development include the existence of educational centers and universities at the provincial level, paying attention to school sports and holding futsal competitions in schools and having a young and interested people. Prioritization of threats based on Friedman's test shows that the most important threats to Sulaymaniyah Football Association Board for futsal development include the lack of sponsors to invest and support futsal clubs, the lack of proper funding for the tournament and the development of futsal clubs and teams, and the involvement of the Sulaymaniyah Football Association Board on political and political issues.

Internal Factor Evaluation Matrix and External Factors Evaluation Matrix. To determine the strategic location of the Sulaymaniyah Football Association Board, Iraq, Internal factor evaluation matrix and external factors evaluation matrix was developed. Then, based on the total score of internal factor evaluation matrix and external factors evaluation matrix, the strategic location of the development of futsal in Sulaymaniyah was identified. Tables 1 and 2 show these two matrices:

Table 1. Internal Factor Evaluation Matrix

\begin{tabular}{|c|c|c|c|c|}
\hline code & Strengths and weaknesses & Weight & Rating & $\begin{array}{c}\text { Rating* } \\
\text { Weight }\end{array}$ \\
\hline S1 & Futsal capacity and ability & 0.09 & 4 & 0.36 \\
\hline S2 & The experience of holding futsal competitions in different age categories at the provincial level & 0.07 & 4 & 0.28 \\
\hline S3 & Having high-level coaches and players at the country level & 0.06 & 4 & 0.24 \\
\hline S4 & Holding the domestic and provincial league matches appropriately & 0.07 & 3 & 0.21 \\
\hline S5 & The existence of a structure called the futsal committee & 0.05 & 3 & 0.15 \\
\hline S6 & Holding scientific and academic training courses for coaches and referees & 0.04 & 3 & 0.12 \\
\hline S7 & Having executive plan for futsal in Sulaimaniyah & 0.03 & 4 & 0.12 \\
\hline S8 & Close cooperation with futsal association board in Iran & 0.04 & 3 & 0.12 \\
\hline W1 & lack of futsal league holding committee and failure to hold a futsal league in the province & 0.02 & 1 & 0.02 \\
\hline W2 & Communication weakness between football federation and training centers in the field of futsal & $0 / 03$ & 1 & 0.03 \\
\hline W3 & Futsal coach and referee shortage & 0.02 & 2 & 0.04 \\
\hline W4 & $\begin{array}{l}\text { Lack of talent identification and talent development in the field of futsal in the Sulaimaniyah } \\
\text { football association board }\end{array}$ & 0.02 & 2 & 0.04 \\
\hline W5 & Insufficient attention of the of the Sulaimaniyah football association board officials to the futsal & 0.05 & 1 & 0.05 \\
\hline W6 & lack of appropriate and suitable space and facilities for futsal & 0.06 & 1 & 0.06 \\
\hline W7 & lack of proper communication between the federation and futsal teams and clubs & 0.03 & 2 & 0.06 \\
\hline W8 & Use non-sports managers in sports responsibilities & 0.04 & 2 & 0.08 \\
\hline W9 & lack of rules and regulations for private sector investment in futsal & 0.04 & 2 & 0.08 \\
\hline W10 & $\begin{array}{l}\text { Failure to comply with the law and regulations in the management of Sulaimaniyah football } \\
\text { association board }\end{array}$ & 0.04 & 2 & 0.08 \\
\hline W11 & Inappropriate use of available spaces and facilities & 0.04 & 2 & 0.08 \\
\hline W12 & Lack of specialist and dedicated management forces especially in the field of sport & 0.05 & 2 & 0.10 \\
\hline W13 & Lack of funds for spending on futsal & 0.06 & 2 & 0.12 \\
\hline \multicolumn{2}{|c|}{ Total score of internal factors } & $\sum=1$ & & $\sum=2.44$ \\
\hline
\end{tabular}


Table 2. External Factors Evaluation Matrix

\begin{tabular}{|c|c|c|c|c|}
\hline Code & Opportunities and Threats & Weight & Rating & $\begin{array}{c}\text { Rating * } \\
\text { Weight }\end{array}$ \\
\hline 01 & Attention to school sports and futsal competitions in schools & 0.09 & 4 & 0.36 \\
\hline $\mathbf{O 2}$ & Having young and interested people & 0.09 & 4 & 0.36 \\
\hline $\mathbf{O 3}$ & Government grants and support of sports activities & 0.07 & 3 & 0.21 \\
\hline $\mathbf{O 4}$ & The press and the media attention to the futsal & 0.05 & 4 & 0.20 \\
\hline 05 & low cost & 0.06 & 3 & 0.18 \\
\hline 06 & $\begin{array}{l}\text { The presence of medical advice on exercise and the increased cost of treatment due to lack of } \\
\text { exercise }\end{array}$ & 0.04 & 4 & 0.16 \\
\hline 07 & Presence of educational centers and universities in the province & 0.05 & 3 & 0.15 \\
\hline $\mathbf{O 8}$ & $\begin{array}{l}\text { Possibility of Take advantage of the experiences of neighboring countries such as Iran and } \\
\text { Turkey }\end{array}$ & 0.05 & 3 & 0.15 \\
\hline T1 & The Sulaimaniyah Football association board involvement in party and political affairs & 0.10 & 1 & 0.10 \\
\hline T2 & Lack of sponsorship for investing and supporting futsal clubs & 0.12 & 1 & 0.12 \\
\hline T3 & departure of prominent players and coaches from the province to attend overseas clubs & 0.06 & 2 & 0.12 \\
\hline T4 & Lack of spectator & 0.10 & 2 & 0.20 \\
\hline T5 & Lack of proper funding for the tournament and the development of futsal clubs and teams & 0.12 & 2 & 0.24 \\
\hline \multicolumn{2}{|c|}{ Total score of external factors } & $\sum=1$ & & $\sum=2.55$ \\
\hline
\end{tabular}

The results of the Table 1 showed that the total score of the internal factor matrix is 2.44 , which is less than 2.5, and indicates that the development of futsal in Sulaimaniyah is in weakness area. The results of the Table 2 showed that the total score of the external factor matrix is 2.55 , which is more than 2.5 , and indicates that the development of futsal in Sulaimaniyah is in Opportunity area.

The Strategic Position of Futsal Development in Sulaimaniyah, Iraq

Internal and external matrix (IE) was used for simultaneous analysis of internal and external factors. In this matrix, the strategic position of futsal development in Sulaimaniyah is in WO position, using the intersection of the total rated weight of the internal factors (2.44) and the total rated weight of the external factors (2.55) (Fig. 1) which shows that weaknesses overcome strengths and opportunities overcome threats. Therefore, the conservative strategies (improving internal weaknesses by exploiting existing opportunities) must be used:

Determine the Strategies for developing futsal Sport in Iraq's Sulaimaniyah Province

In this regard, at the comparative stage, according to internal and external factors and based on the SWOT analysis and final approval of the Strategic Council, a total of 21 strategies, including seven SO strategies, four ST strategies, seven WO strategies, and three WT strategies was developed for the futsal development of Sulaimaniyah:

\section{DISCUSSION}

This research was aimed at developing a strategic plan for futsal development in Sulaimaniyah province, Iraq. Matrix of strengths, weaknesses, opportunities and threats is one of the important tools that managers compare information with and can present four types of strategies: SO, WO, ST and WT (11).

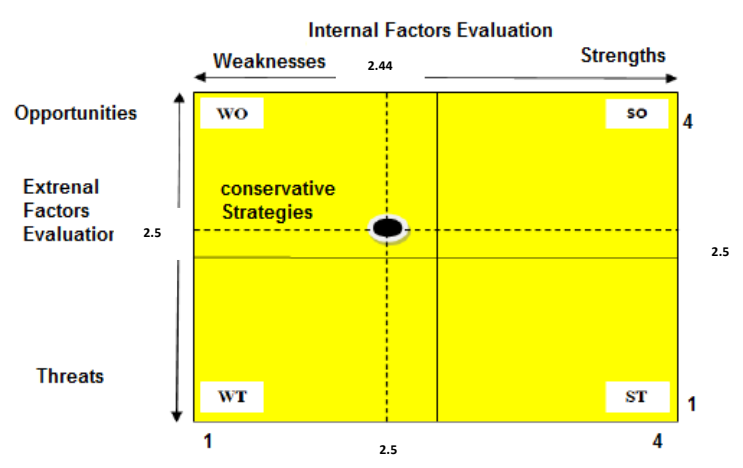

Figure1. Strategic Position based on the Final Score of the Internal and External Assessment Matrix

The results showed that the strategic location of the futsal development in Sulaimaniyah, using the intersection of the total rated weight of the internal factors (2.44) and the total rated weight of the external factors (2.55) is in WO region, which shows that weaknesses overcome strengths and opportunities overcome threats. Therefore, conservative strategies should be used. Compared with the studies, Shafiee et al. (2017) showed the strategic situation of football in Golestan province in WT region (15), Ramezani nejad et al. (2018) showed the strategic situation of football in Gilan province in WT region (16), and Rezaei Soufi and Shabani (2016) showed the strategic situation of athletic sport in Iran in WT region (17), and used the appropriate strategies for the situation. 
Table 3. TOWS Matrix for the Futsal Development of Sulaimaniyah

\begin{tabular}{|c|c|c|}
\hline EFE & $\begin{array}{l}\text { Strength (S) } \\
\text { S1: Holding scientific and academic training } \\
\text { courses for coaches and referees. } \\
\text { S2: Having high-level coaches and players at } \\
\text { the country level. } \\
\text { S3: The experience of holding futsal } \\
\text { competitions in different age categories at the } \\
\text { provincial level. } \\
\text { S4: The existence of a structure called the futsal } \\
\text { committee. } \\
\text { S5: Holding the domestic and provincial league } \\
\text { matches appropriately. } \\
\text { S6: Having executive plan for futsal in } \\
\text { Sulaimaniyah. } \\
\text { S7: Futsal capacity and ability. } \\
\text { S8: Close cooperation with futsal association } \\
\text { board in Iran. }\end{array}$ & $\begin{array}{l}\text { Weakness (W) } \\
\text { W1: Lack of funds for spending on futsal } \\
\text { W2: lack of rules and regulations for private } \\
\text { sector investment in futsal. } \\
\text { W3: lack of proper communication between the } \\
\text { federation and futsal teams and clubs. } \\
\text { W4: lack of appropriate and suitable space and } \\
\text { facilities for futsal. } \\
\text { W5: Lack of specialist and dedicated } \\
\text { management forces especially in the field of } \\
\text { sport. } \\
\text { W6: Communication weakness between football } \\
\text { federation and training centers in the field of } \\
\text { futsal. } \\
\text { W7: Use non-sports managers in sports } \\
\text { responsibilities. } \\
\text { W8: lack of futsal league holding committee and } \\
\text { failure to hold a futsal league in the province. } \\
\text { W9: Insufficient attention of the of the } \\
\text { Sulaimaniyah football association board officials } \\
\text { to the futsal. } \\
\text { W10: Lack of talent identification and talent } \\
\text { development in the field of futsal in the } \\
\text { Sulaimaniyah football association board. } \\
\text { W11: Futsal coach and referee shortage. } \\
\text { W12: Failure to comply with the law and } \\
\text { regulations in the management of Sulaimaniyah } \\
\text { football association board. } \\
\text { W13: Inappropriate use of available spaces and } \\
\text { facilities. }\end{array}$ \\
\hline $\begin{array}{l}\text { Opportunities (O) } \\
\text { O1: Attention to school sports and futsal } \\
\text { competitions in schools. } \\
\text { O2: The press and the media attention to } \\
\text { the futsal. } \\
\text { O3: Government grants and support of } \\
\text { sports activities. } \\
\text { O4: Presence of educational centers and } \\
\text { universities in the province. } \\
\text { O5: Having young and interested people. } \\
\text { O6: Possibility of Take advantage of the } \\
\text { experiences of neighboring countries } \\
\text { such as Iran and Turkey. } \\
\text { O7: presence of medical advice on } \\
\text { exercise and the increased cost of } \\
\text { treatment due to lack of exercise. } \\
\text { O8: low cost Futsal. }\end{array}$ & $\begin{array}{l}\text { SO strategies } \\
\text { SO1: Support and reinforcement of futsal } \\
\text { tournament in girls 'and boys' schools. } \\
\text { SO2: Organizing regular leagues and domestic } \\
\text { and provincial matches. } \\
\text { SO3: Organizing regular provincial } \\
\text { tournaments youths, teens, young. } \\
\text { SO4: Collaboration with other academic and } \\
\text { scientific institutions. } \\
\text { SO5: Creating continuous and constructive } \\
\text { engagement with neighboring countries in } \\
\text { order to take advantage of experiences. } \\
\text { SO6: Supporting top clubs for national and } \\
\text { international competition. } \\
\text { SO7: supporting talent identification Base } \\
\text { Futsal. }\end{array}$ & $\begin{array}{l}\text { WO strategies } \\
\text { WO1: Maximum use of available sports space } \\
\text { and facilities. } \\
\text { WO2: Changes in the organizational structure of } \\
\text { Sulaimaniyah football association board. } \\
\text { WO3: Absorption of funds for the development } \\
\text { of per capita sports space in a low-budget city. } \\
\text { WO4: Strengthening investment and attracting } \\
\text { private sector support. } \\
\text { WO5: Increasing the number of trainers through } \\
\text { Holding training courses and upgrading coaches' } \\
\text { level. } \\
\text { WO6: Increasing the number of referees through } \\
\text { holding training courses and upgrading the level } \\
\text { of referees. } \\
\text { WO7: Use of available facilities in other } \\
\text { departments and institutions. }\end{array}$ \\
\hline $\begin{array}{l}\text { Threats (T) } \\
\text { T1: Lack of funds for holding matches } \\
\text { and developing futsal clubs and teams. } \\
\text { T2: Lack of sponsorship for investing and } \\
\text { supporting futsal clubs. } \\
\text { T3: Lack of spectator. } \\
\text { T4: The Sulaimaniyah Football } \\
\text { association board involvement in party } \\
\text { and political affairs. } \\
\text { T5: departure of prominent players and } \\
\text { coaches from the province to attend } \\
\text { overseas clubs. }\end{array}$ & $\begin{array}{l}\text { ST strategies } \\
\text { ST1: Program-driven management and } \\
\text { rulemaking. } \\
\text { ST2: Use of media capacity to increase people's } \\
\text { interest in futsal. } \\
\text { ST3: Increasing the number and variety of } \\
\text { community events and sports festivals. } \\
\text { ST4: Conducting Annual Scientific Meetings } \\
\text { and Conferences of Referees and Coaches. }\end{array}$ & $\begin{array}{l}\text { WT strategies } \\
\text { WT1: Development of cooperation of } \\
\text { Sulaimaniyah Football association board with } \\
\text { other state institutions } \\
\text { WT2: Updating processes, indicators and } \\
\text { programs } \\
\text { WT3: The use of sports specialist managers in } \\
\text { futsal sports posts }\end{array}$ \\
\hline
\end{tabular}

The main strengths of the Sulaimaniyah Futsal association board for the development of futsal include holding scientific and academic training courses for coaches and referees, Having highlevel coaches and players throughout the country and having an executive program for the futsal in Sulaimaniyah province. Ramezani nezhad et al. (2018) considered the number of international coaches as the strengths of football development in Guilan province (16). Willem et al. (2018) points out the existence of sports associations as a major milestone in the development of public sport (18).

Lack of financial resources for spending on futsal, lack of proper sporting facilities for futsal, and lack of rules and regulations for private sector 
investment in futsal are from the most important weaknesses of the Sulaimaniyah Football association board to develop futsal. Rezaei and Nasir zadeh (2018) mentioned the lack of laws and regulations as one of the most important weaknesses of privatization in the Iranian football industry (6). Moslemi et al. (2018) considered the lack of participation and investment of the private sector as the main obstacle to the development of traditional indigenous sports in Kerman province (19). McGillivary et al. (2018) noted the lack of attention to urban policies and planning as the weak points of physical development of sport in cities (13).

Some of the most important opportunities for futsal development in the Sulaimaniyah are in importance, including the presence of educational centers and universities in the province, the focus on sports schools, the holding of futsal competitions in schools, and having young and interested people. Kashef et al. (2018) described the youth's interest in sports as the most important opportunities for the development of the championship sport in East Azerbaijan province (12). Rezaei and Salehipour (2018) emphasized on student sport as a great opportunity for sports development in Iran (20). Mokhtarin et al. (2011) suggest that the presence of young people in each country is a great opportunity, which attention to that will lead to the development of sport (21).

Also, some of the most important threats to the development of futsal in this province include lack of sponsorship for investment and support for futsal clubs, lack of proper funding for the tournament and the development of clubs and the involvement of the Sulaimaniyah football association board in political and party affairs. Shafiee et al. (2017) noted the lack of funding for football related projects in the province as a serious threat to football development in Golestan province (15). Rezaie and Salehipour (2018) stated that the entry of governmental and quasigovernmental retired to sport as a major threat to the development of sport in Iran (20). Hambrick et al. (2018) described the lack of resources and dependence on other organizations as one of the most important threats to the development of sports organizations (14).

At the stage of matching and comparison, according to identified internal and external factors and based on analysis SWOT and the final approval of the Strategic Council, a total of 21 strategies, including 7 SO Strategy, 4 ST Strategy,
7 WO Strategy and 3 WT Strategy, developed for the development of Futsal in Sulaimaniyah. Some of the most important strategies include increasing the number and variety of collective events and sports festivals, Maximum use of existing space and sports facilities, regular leagues and local and provincial competitions, and the annual holding of scientific conferences and contests of referees and coaches. Sajjadi et al. (2016) cite the development of federation partnerships with the country's education and higher education centers as an offensive strategy, the development of a comprehensive talent program as a conservative strategies, the use of available opportunities and capacities to attract sponsors as a competing strategies, and the development of the chess federation's marketing strategy program as a defensive strategies to develop the chess federation (22). Shafiee et al. (2017) considered management intervention to reduce the impact of non-football players as competitive strategies, Conducting training courses and justification of base football in the province to increase the technical and scientific capacity of coaches of football schools as conservative strategies, and Increasing the resources and financial resources of the Football Association as defensive strategies and development of provincial football management system as aggressive strategies for football development in Golestan province (15). Ramezani nezhad at al. (2018) stated using successful managers of other sports sectors as aggressive strategies, developing infrastructure and equipment as competitive strategies and using media power as conservative strategies for the development of football in the Guilan province (16).

\section{CONCLUSION}

In general, it can be stated that due to the causal relationship between the different perspectives of the strategic plan and in view of the strengths and opportunities of processing football association board of Sulaimaniyah, Iraq, the strategic plan developed suggesting a good picture of the achievement of the Sulaymaniyah football association board goals. Therefore, it is expected that football association board of Sulaimaniyah will be able to play a good role in fulfilling the prospect of futsal by utilizing these capabilities. Because both in the indoor environment and in the external environment the conditions have been in favor of the development 
of futsal, most strategies derived from the strategy definition matrix are based on futsal development. Therefore, Sulaymaniyah football association board seems to be well equipped to cover the weaknesses, confronting threats of perimeter environment and maximum use of opportunities. Finally, the elaboration of different perspectives of the futsal development program in Sulaymaniyah provides an appropriate platform for the implementation of the program, and obtained strategic plan provides managers and staff with a clear picture of the route ahead, through the elements envisaged in it. Hence the adoption of a pivotal approach and the implementation of strategies with considering the perspective and predicted macro goals, Could contribute to the macro development indicators of futsal development in Sulaimaniyah, Iraq. Lastly, given the strategic position of Sulaimaniyah's futsal sport in the WO area, provincial sports authorities should focus their programs on addressing the weaknesses and increasing opportunities for futsal sports and use the growth and development strategy for the province's futsal sport.

\section{APPLICABLE REMARKS}

- It is suggested that specialized working groups be designed for appropriate executive and operational programs and predict financial, human and facility resources to implement it.

- The strategies to increasing the number and variety of community events and sports festivals, maximum use of available sports space and facilities and organizing regular leagues and domestic and provincial matches have been proposed to remove current condition of futsal in Sulaymaniyah province.

- The results of SWOT analysis show that weaknesses overcome strengths and opportunities over threats, so conservative strategies (Improve internal weaknesses by exploiting existing opportunities) should be used.

\section{REFERENCES}

1. Kirchengast S. Physical Inactivity from the Viewpoint of Evolutionary Medicine. Sports. 2014;2(2):34-50. doi: 10.3390/sports2020034

2. Mehdi Zadeh R, Andam R. Strategies for General Sports Extensions in Iranian Universities. Sport Manage. 2014(2):15-38.

3. Arabi S, Chavoshi D. A Study of Relationship between Strategic Control Style and Performance of Holding Companies Listed in Tehran Stock Exchange. J Strategic Manage Stud. 2010(1):7-26.

4. Javadi Pour M, Samie Nia M. Explanation of strategic position and presentation of development strategy in sport for all in Iran. Contemp Stud Sport Manage. 2013;2(3):15-28.

5. Razavi S, Niazi S, Boroumand D. Designing and developing a strategy for the development of sport for all using scientific perspective in Mashhad. Appl Res Sport Manage. 2014;4(3):49-60.

6. Rezaei S, Nasir Zadeh A. Environmental analysis assignment football clubs in Iran Case study: Esteghlal and Persepolis clubs. Appl Res Sport Manage. 2018;7(1):105-115.

7. Khosravi Zadeh E, Hamidi M, Yadolahi J, Khabiri M. Developing strategies and determining strategic situation of NOC of Islamic Republic of Iran. Sport Dev Manage. 2012;1(1):11-25.

8. Goudarzi M, Nasirzadeh A, Farahan A, Vatan Doust M. The Design and Codification of Development Strategy of Sport for All in Kerman Province. Sport Manage. 2013;2(149-172).

9. Namada JM, Bagire V, Aosa E, Awino ZB. Strategic Planning Systems and Firm Performance in the Export Processing Zones. Am J Ind Busin Manage. 2017;07(04):487-500. doi: 10.4236/ajibm.2017.74035

10. Teixeira GFG, Canciglieri Junior O. How to make strategic planning for corporate sustainability? $J$ Clean Prod. 2019;230:1421-1431. doi: 10.1016/j.jclepro.2019.05.063

11. Saeimian S, Arghandeh R. The investigation of globalization with approach to SWOT. J Manage. 2008;18(12):21-27.

12. Kashef S, Sayyed Ameri M, Ahmadi M, Marefat D. Providing Strategic Model of Athletic Sports Development in East Azerbaijan Province, by Using SWOT and BSC. Appl Res Sport Manage. 2018;6(4):27-37.

13. McGillivray D. Sport events, space and the 'Live City'. Cities. 2019;85:196-202. doi: 10.1016/j.cities.2018.09.007 
14. Hambrick ME, Svensson PG, Kang S. Using social network analysis to investigate interorganizational relationships and capacity building within a sport for development coalition. Sport Manage Rev. 2018. doi: 10.1016/j.smr.2018.12.002

15. Shafiee S, Rostami H, Mamashloo H, Deh Panah S. SWOT Analysis of Golestan Province's Football and Delivering Suitable Strategies. Sport Dev Manage. 2017;6(2):119-140.

16. Ramzani Nezhad R, Shafiee S, Rostami H. Strategic Pathology of Guilan Province Football and Determining a Desirable Strategy. Sport Dev Manage. 2019;7(14):120-139.

17. Rezaei Soufi M, Shabani A. The Analysis of Athletic Sports in Iran: SWOT Analysis. Sport Dev Manage. 2017;6(1):87-103.

18. Willem A, Girginov V, Toohey K. Governing bodies of sport as knowledge brokers in Sport-forAll communities of practice. Sport Manage Rev. 2018. doi: 10.1016/j.smr.2018.08.005

19. Moslemi A, Ghofrani M, Saberi A. Design and Codification of Development Strategy of LocalTraditional Sports in Kerman Province. Sport Manage. 2019;10(1):85-102.

20. Rezaei S, Salehipour M. Analysis of Effective Factors in Development of Iran Sport Industry using Grounded Theory Approach. J Hum Resour Manage. 2019;6(1):89-107.

21. Mokhtarian M, Khodayari A, Nourbakhsh M. Identifying the opportunities and threats of sport climbing in Iran. Eur J Exp Biol. 2014;4(1):110-116.

22. Sajjadi S, Khabiri M, Ghaem Maghami E, Benesbordi A. Identification and developing Strategies of Islamic republic of Iran Chess Federation. Sport Dev Manage. 2016;5(2):18-33. 